DOI https://doi.org/10.18551/rjoas.2018-10.23

\title{
STRATEGY OF BEEF CATTLE LIVESTOCK DEVELOPMENT IN GUNUNGKIDUL DISTRICT, INDONESIA
}

\author{
Triyanto* \\ Postgraduate Program, Sebelas Maret University, Indonesia
}

Rahayu Endang Siti, Purnomo Sutrisno Hadi, Lecturers

Faculty of Agriculture, Sebelas Maret University, Indonesia

*E-mail: triyanto.pertanian@gmail.com

\begin{abstract}
This study aims to identify the internal and external factors and analyze the alternative strategies which can be applied in developing beef cattle in Gunungkidul District. The method used in this study is mixed method of qualitative and quantitative to collect the primary data from the respondents and secondary data from relevant institutions, which are BPS (Statistics Indonesia) of Gunungkidul District, Agriculture and Food Services of Gunungkidul District. The research sample was determined by convenience sampling as many as 60 breeder respondents and 12 expert respondents from instances and private sector. The data analysis uses internal and external situation analysis and SWOT analysis. The qualitative SWOT analysis on internal factors results in the identification of strengths and weaknesses which consist of human resources, financial conditions, operational/ production, management, and marketing. The analysis on external factors results in the identification of external factors in the form of opportunities and threats consisting of social, economic, government policy and technology. The quantitative SWOT matrix analysis results in an internal factor of 0.81 (on the $x$ axis) and an external factor of 1.16 (on the y axis). Strategic position is in quadrant I which means as supporting aggressive growth policies (Growth Oriented Strategy), which is using the power to obtain opportunities (SO). SO alternative strategy formulated is the increased population and production, optimizing the potential of human resources potential of breeder and supporting the animal feed waste as well as facilities and infrastructures and improving a good management and technical skills.
\end{abstract}

\section{KEY WORDS}

SWOT analysis, beef cattle, development, strategy.

The development of the livestock sub-sector, especially the beef cattle commodity, has an important role in the regional economy structure. The development of beef cattle commodities is an alternative choice because in reality, this livestock has an important role in improving the community welfare. Thus, some local governments determine beef cattle as one of the superior commodities to be developed. Suryana (2009) states that beef cattle is one of the ruminants which has the largest contribution as meat producers. The increasing demand for beef opens the opportunity for the development of local beef cattle livestock on an agribusiness scale through a partnership pattern. The beef cattle agribusiness system can also alleviate poverty and create job opportunity in rural areas (Sarma, 2014).

Gunungkidul District has the largest beef cattle population in DIY (Special Region of Yogyakarta) with a population of 150,331 from the total population of DIY province as many as 309,018 or $48.65 \%$ (BPS DIY, 2017). The territory of Gunungkidul District has a mountainous dry land ecosystem. Therefore, the forage is abundantly available during the rainy season and decreases in the dry season. In the dry season, breeders use rice straw and groundnut straw as the cattle feed (Agricultural Agency of DIY, 2015). This is in line with Wirdahayati's opinion (2010) that efforts to improve feed, utilization of local feed ingredients and waste of crops which are easily accessed by the breeders, have opened up opportunities for livestock development efforts without depending on the extensive traditional 
pattern which only relies on natural pasture. The result of other studies indicates that the use of the following results at certain limits provides a positive response to livestock productivity (Mariyono and Krishna, 2009).

Problems in the livestock sector in Gunungkidul District include problems with the unavailability of food and water for all year, unstable selling prices and narrow land. The maintenance of beef cattle in Gunungkidul District is carried out from generation to generation or traditionally, with the main function is as savings, utilizing agricultural waste, social status and side businesses. The problem which arises is the provision of beef cattle cannot rely on smallholder livestock only. Thus, it is required to do a quick solution which is importing the beef from developed countries whose farming systems are already resilient (Development Planning Agency at Sub-National Level of Gunungkidul District, 2016). Efforts to overcome these problems require development strategies which focus on the right targets. Livestock development in Gunungkidul District uses the approach or concept of "livestock self-sufficiency in Gunungkidul by strengthening profit-oriented based institutions as well as reproduction and maintenance management" (Development Planning Agency at SubNational Level of Gunungkidul, 2016).

Gunungkidul District as an area for the development of beef cattle livestock is based on several important reasons including the availability of potential natural resources and human resources and its potential to be developed, the existence of animal markets, the sufficient number of livestock, and strategic geographical location. Seeing these conditions, this area still has the opportunity to develop further. This study aims to identify the internal and external factors which affect the development of beef cattle livestock in Gunungkidul District and analyzing the alternative strategies which can be applied in developing beef cattle livestock in Gunungkidul District.

\section{METHODS OF RESEARCH}

This research was carried out in March to July 2018 in Gunungkidul District, DIY Province. The research location was chosen intentionally (purposive sampling) because Gunungkidul District has a contribution to the livestock sector, especially beef cattle in DIY Province with a population of 150,331. Since they have animal market, access of supporting infrastructure and facilities, sufficient natural resources and human resources.

This study uses a mixed qualitative and quantitative method to get more comprehensive result. The determination of the sample is done by convenience sampling with 60 respondents of beef cattle breeders and 12 respondents of expert consists of 1 person from the Provincial Agriculture Office, 2 people from the Agriculture and Food Service Office of Gunungkidul District, 1 person from the animal expert, 1 person from Development Planning Agency at Sub-National Level, 1 person from BPTP (Agricultural Technology Assessment Center) Yogyakarta, 2 academics/ lecturers, 2 group leaders (breeders) and 2 people from the head of Gapokbitnak, and 2 food vendors and traders.

Sixty respondents from the breeders were used to find out the data of breeder characteristics, management of beef cattle cultivation and the supporting data in order to identify the internal and external factors in formulating the strategy. Meanwhile, 12 key informants or experts are the informants to identify the internal and external factors as well as the assessment of identification results which will be formulated into strategies. The data collection was conducted by identifying and assessing using questionnaire and interview.

Qualitative primary data is described and tested using a SWOT matrix. The SWOT matrix is an important matching tool to help managers developing 4 types of strategies. The four strategies are SO (Strength-Opportunity) strategy, WO (Weakness-Opportunity) strategy, ST (Strength-Threat) strategy and WT (Weakness-Threat) strategy. The quantitative primary data was collected by using a questionnaire and the result obtained is in the form of numbers which then is calculated by the mean method. The details of internal and external factors was obtained and results in the total amount in the form of scores. 


\section{RESULTS AND DISCUSSION}

The territory of Gunungkidul District is located between $7^{\circ} 46^{\prime}-8^{\circ} 09^{\prime}$ South Latitude and $110^{\circ} 21^{\prime}-110^{\circ} 50^{\prime}$ East Longitude. It borders Klaten District and Sukoharjo District, Central Java in the north; Wonogiri District, Central Java in the east; Indonesian Ocean in the south; and Bantul District and Sleman District, DI Yogyakarta in the west. The total area of Gunungkidul District is $1,485.36 \mathrm{Km}^{2}$ covering 18 sub-districts and 144 villages with a total population of around 704,026 people, the number of heads of households is 206,708 households, and the population density per district at an average of 473.98 people $/ \mathrm{km}^{2}$. The population of beef cattle in Gunungkidul District develops every year since it is suitable to be developed in Gunungkidul District. The development of beef cattle population from 20142016 were 140,928; 147,195 and 148,856 respectively (BPS of Gunungkidul District, 2016).

The age characteristic of the respondents of beef cattle breeders in Gunungkidul District is between $20-50$ years old or $76.67 \%$. This shows that the age of beef cattle breeders in Gunungkidul District is still in the productive age. Anggraini and Putra's (2017) research result shows that the productive age of beef cattle breeders in Sijunjung Subdistrict, Sijunjung District, West Sumatra is between the age of 25-55 years old. This shows that the ability of the breeders to develop beef cattle business still have potential, which means that the available power is still strong enough to work.

Table 1 - Characteristics of Respondents in Gunungkidul District

\begin{tabular}{|c|c|c|}
\hline Characteristics & Respondent (person) & Percentage (\%) \\
\hline \multicolumn{3}{|l|}{ Age (Years Old) } \\
\hline$<20$ & 0 & 0 \\
\hline $20-50$ years old & 46 & 76.67 \\
\hline$>50$ years old & 14 & 23.33 \\
\hline Total & 60 & 100 \\
\hline \multicolumn{3}{|l|}{ Gender } \\
\hline Male & 57 & 95.00 \\
\hline Female & 3 & 5.00 \\
\hline Total & 60 & 100 \\
\hline \multicolumn{3}{|l|}{ Level of Education } \\
\hline Do not graduate the elementary school & 1 & 1.67 \\
\hline Elementary School & 34 & 56.67 \\
\hline Junior High School & 19 & 31.67 \\
\hline Senior High School & 6 & 10.00 \\
\hline Total & 60 & 100 \\
\hline \multicolumn{3}{|l|}{ Experience of being breeder (Years) } \\
\hline$<5$ & 4 & 6.67 \\
\hline $5-10$ & 23 & 38.33 \\
\hline $10-15$ & 21 & 35.00 \\
\hline$>15$ & 12 & 20.00 \\
\hline Total & 60 & 100 \\
\hline \multicolumn{3}{|l|}{ Main Occupation } \\
\hline Farmer/Breeder/Labor & 60 & 100 \\
\hline Total & 60 & 60 \\
\hline \multicolumn{3}{|c|}{ Number of Family Members involved (person/s) } \\
\hline 1 & 4 & 6.67 \\
\hline 2 & 47 & 78.33 \\
\hline 3 & 9 & 15.00 \\
\hline Total & 60 & 100 \\
\hline
\end{tabular}

Source: Primary Data processed, 2018.

Based on table 1 the majority of respondents are male as many as 57 respondents $(95 \%)$, and only 3 respondents are female $(5 \%)$. It proves that the respondents of beef cattle breeders are dominated by male breeders since beef cattle cultivation requires prime power and heavier handling, feeding, cleanliness of the cage, and marketing.

The level of education of the respondents is mostly elementary school, which are 34 people $(56.67 \%)$. It shows that most respondents have a low level of education. According to Hoda (2002), formal education is an early indicator which can be used to determine the ability of breeder in adopting new information and innovation as the level of education is very influential on mindset changes. The experience of breeding of the respondents between is 
mostly for $5-15$ years which is 44 people $(73.33 \%)$. It shows that the respondents of beef cattle breeders in Gunungkidul District have had enough cattle breeding experience. The longer the breeders run the business, the more experience they get, so that it can be used as a guide in dealing problems in running a beef cattle business (Suresti, 2012). According to Waris et. al., 2015, it is known that the long-term rate of breeding experience has a significant effect on the beef cattle reproductive management insight.

Table 2 - Identification of Internal and External Analysis

\begin{tabular}{|c|c|c|}
\hline Internal Factor & Strength & Weakness \\
\hline Human Resource & $\begin{array}{l}\text { Breeders have the unyielding / resilient } \\
\text { nature } \\
\text { Have sufficient breeding experience }\end{array}$ & $\begin{array}{l}\text { Low motivation to change business } \\
\text { orientation to business profit }\end{array}$ \\
\hline Operational/ Production & $\begin{array}{l}\text { The potential for a large number of beef } \\
\text { cattle population/ is the beef cattle base } \\
\text { area } \\
\text { The business of beef cattle cultivation is } \\
\text { easy to do }\end{array}$ & $\begin{array}{l}\text { Business as a side occupation or savings } \\
\text { Has a characteristic of traditional with } \\
\text { individual housing system and a small } \\
\text { business scale } \\
\text { The utilization of processing of agricultural } \\
\text { waste for the feeding is not optimal } \\
\text { Some areas experience a lack of forage in } \\
\text { the dry season }\end{array}$ \\
\hline Marketing & $\begin{array}{l}\text { The marketing of livestock products is } \\
\text { easy through cattle seller } \\
\text { The availability of animal markets and } \\
\text { access to transportation making it easy } \\
\text { to market the beef cattle }\end{array}$ & $\begin{array}{l}\text { The absence of planning in the sale of } \\
\text { livestock as it is only based on needs and } \\
\text { pricing based on estimation. }\end{array}$ \\
\hline Capital Condition & The capital spent is relatively low & $\begin{array}{l}\text { Capital limitation to develop business and } \\
\text { the difficult access to Banking }\end{array}$ \\
\hline Management & $\begin{array}{l}\text { Group institutions have gone well (most } \\
\text { breeders are group members) } \\
\text { Regular recording (population) has been } \\
\text { done by groups/ some breeders }\end{array}$ & $\begin{array}{l}\text { Cultivation management implementation is } \\
\text { not quite well. }\end{array}$ \\
\hline External Factor & Opportunity & Threat \\
\hline Economy & $\begin{array}{l}\text { The market or demand for beef is still } \\
\text { open } \\
\text { The availability of credit facilities from } \\
\text { banks with low interest }\end{array}$ & $\begin{array}{l}\text { Fluctuation in the price of meat and beef } \\
\text { cattle } \\
\text { The role of the blantik (cow seller) greatly } \\
\text { determines the price of livestock }\end{array}$ \\
\hline Social and cultural & $\begin{array}{l}\text { The trend of increasing demand for } \\
\text { livestock for religious activities increases }\end{array}$ & $\begin{array}{l}\text { The conversion of agricultural/ livestock } \\
\text { land to other sectors }\end{array}$ \\
\hline Government Policies & $\begin{array}{l}\text { Government program facilities in the } \\
\text { form of livestock assistance and group } \\
\text { development } \\
\text { Determination of Gunungkidul District as } \\
\text { the territory of the Beef Cattle Seed } \\
\text { Source }\end{array}$ & $\begin{array}{l}\text { Budget limitations or local government } \\
\text { funds to support the development of beef } \\
\text { cattle farms } \\
\text { The government policy of importing beef } \\
\text { cattle seems to be less favorable to the } \\
\text { breeders }\end{array}$ \\
\hline Technology & $\begin{array}{l}\text { Availability of HPT (Limited Production } \\
\text { Forest) processing technology } \\
\text { There has been widespread of IB } \\
\text { technology and handling of reproductive } \\
\text { problem by breeder }\end{array}$ & Technology application which less efficient \\
\hline
\end{tabular}

Source: Primary Data processed, 2018.

The main occupation of the respondents is breeders, while beef cattle livestock is a side business. Breeder raise cattle only to their free time after they farming. In addition, the breeders also consider the purpose of livestock as savings. The number of family members involved in the management of beef cattle business is on average of 2 people or $78.33 \%$ where the role of the family is more dominant, and does not use external labor which aims to minimize the cost. Mukson et al., (2008) state that the labor in beef cattle breeding business generally still uses family labor and is widely used for food seeking activities which are usually carried out together with the agricultural activities.

The SWOT analysis is qualitatively carried out by identifying the internal and external factors which affect the development of beef cattle breeding in Gunungkidul District, in which 
the identification was done according to the condition of the region. The development strategy for beef cattle breeding can be obtained by referring to the identification of the strengths, weaknesses, opportunities and threats of the SWOT analysis. The identification of internal and external factors can be seen in table 2 .

In order to support the qualitative SWOT analysis, a quantitative SWOT analysis is conducted as well. SWOT analysis is used to determine the effect of internal and external factor of beef cattle business which are strength, weakness, opportunity and threat. Based on the internal factors, the development strategy of beef cattle livestock consists of strength and weakness identified based on the conditions which occur at the research location. The result shows that the weighted mean of strengths - the weighted mean of weaknesses $=1.71$ $-0.90=0.81(x)$. It can be seen in Table 3 . The external factor is the business environment which creates the opportunity and threat faced by cattle livestock in Gunungkidul District. Based on these external factors, it can be identified the opportunity and threat faced in beef cattle business. The result shows that the weighted mean of opportunity - the weighted mean of threat $=2.00-0.84=1.16(\mathrm{y})$. The calculation result can be seen in Table 4. Appropriate strategy in the development of beef cattle livestock (assessment reference for the development of beef cattle livestock is in quadrant I) is by using the power to obtain opportunity as can be seen in Figure 2.

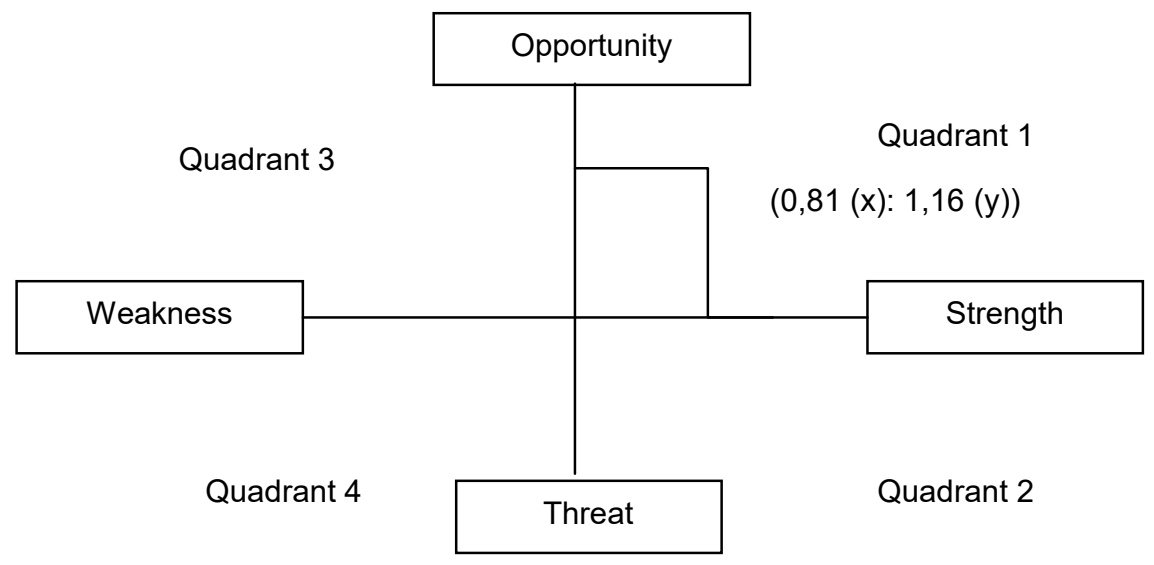

Figure 2 - SWOT Analysis of Beef Cattle Livestock Development in Gunungkidul District

Alternative development strategy which can be formulated using a SWOT matrix is still a series of the previous stages. The SWOT matrix clearly illustrates the combination of internal factors and external factors so that alternative strategies can be produced. SWOT matrix has four possible alternative strategy cells, which are SO, WO, WT, and ST strategies. The combination of internal and external factors will obtain several alternative strategies which can be applied in the development of beef cattle livestock in Gunungkidul District.

In detail, there are four types of alternative strategies which can be applied in developing beef cattle business in Gunungkidul District, those are: SO strategy or strengthopportunity strategy which is a strategy using internal power in order to be able to take advantage of external opportunities. An alternative SO strategy formulated is an increase of population and production of beef cattle in each sub-district based on the existing potential. The increase of beef cattle population is by looking at the condition of each sub-district area and the availability of resources. Priyanto (2011) explains that the development of beef cattle livestock requires regional basis grouping which is adjusted to carrying capacity as a future development model. The mapping of business development areas (new sources of growth) with both breeding and fattening patterns is needed to support the increase in livestock population. One suggestion which needs to be considered is to concentrate the program on a certain area with intensive supervision. The program must be accompanied by an increase in forage and all supporting things such as irrigation and tillage (Yusdja et al., 2003). 
Table 3 - Internal Strategy Factors for the development of beef cattle livestock

\begin{tabular}{|c|c|c|c|c|}
\hline No. & Strengths & Weight & Rating & $\begin{array}{l}\text { Mean Total } \\
\text { Score }\end{array}$ \\
\hline 1. & $\begin{array}{l}\text { Regular recording (population) has been done by groups/ some } \\
\text { breeders }\end{array}$ & 0.065 & 3.00 & 0.20 \\
\hline 2. & Breeders have the nature of never giving up/ resilience & 0.068 & 4.00 & 0.27 \\
\hline 3. & Have sufficient breeding experience & 0.057 & 3.00 & 0.17 \\
\hline 4. & $\begin{array}{l}\text { Have the potential for a large number of beef cattle population/ is the } \\
\text { beef cattle base area }\end{array}$ & 0.068 & 3.00 & 0.20 \\
\hline 5. & Beef cattle livestock business is easy to do & 0.054 & 3.00 & 0.16 \\
\hline 6. & The capital cost incurred is relatively low & 0.068 & 3.00 & 0.20 \\
\hline 7. & Availability of food crop waste as a source of forage feed & 0.057 & 3.00 & 0.17 \\
\hline 8. & $\begin{array}{l}\text { Group organization has been going well (most breeders are group } \\
\text { members) }\end{array}$ & 0.060 & 3.00 & 0.18 \\
\hline \multirow[t]{2}{*}{9.} & $\begin{array}{l}\text { The availability of animal market and transportation access making it } \\
\text { easy to market beef cattle }\end{array}$ & 0.051 & 3.00 & 0.15 \\
\hline & Total & 0.548 & & 1.71 \\
\hline No. & Weakness & & & \\
\hline 1. & Limited business capital and difficulty in accessing capital to bank & 0.060 & 2.00 & 0.12 \\
\hline 2. & Low motivation to change business orientation to profit/ business & 0.065 & 2.00 & 0.13 \\
\hline 3. & Business as a side occupation or savings & 0.051 & 2.00 & 0.10 \\
\hline 4. & $\begin{array}{l}\text { Have the cracteristic of traditional with individual housing system and } \\
\text { small business scale }\end{array}$ & 0.051 & 2.00 & 0.10 \\
\hline 5. & The application of good cultivation management is still lacking & 0.051 & 2.00 & 0.10 \\
\hline 6. & Some areas experience a lack of forage in the dry season & 0.068 & 2.00 & 0.14 \\
\hline 7. & Utilization/ processing of agricultural waste for feed is not optimal & 0.054 & 2.00 & 0.11 \\
\hline \multirow[t]{3}{*}{8.} & There is no planning in sales and pricing is based on estimation & 0.051 & 2.00 & 0.10 \\
\hline & Total & 0.452 & & 0.90 \\
\hline & Total & 1.000 & & 2.62 \\
\hline
\end{tabular}

Source: Primary Data processed, 2018.

Table 4 - Internal Strategy Factors for the development of beef cattle livestock

\begin{tabular}{|c|c|c|c|c|}
\hline No. & Opportunities & Weight & Rating & $\begin{array}{l}\text { Mean Total } \\
\text { Score }\end{array}$ \\
\hline 1. & The market or demand for beef is still open & 0.092 & 3.00 & 0.28 \\
\hline 2. & \multirow{2}{*}{$\begin{array}{l}\text { Availability of credit facilitation (KUR) from Bank BRI with low interest } \\
\text { Facilities of government program in the form of livestock assistance } \\
\text { and group development }\end{array}$} & 0.074 & 4.00 & 0.30 \\
\hline 3. & & 0.074 & 3.00 & 0.22 \\
\hline 4. & $\begin{array}{l}\text { Determination of Gunungkidul District as the area of the Beef Cattle } \\
\text { Seed Source }\end{array}$ & 0.085 & 3.00 & 0.25 \\
\hline 5. & The trend of increasing demand for religious activities increases & 0.074 & 4.00 & 0.30 \\
\hline 6. & Availability of HPT processing technology & 0.096 & 3.00 & 0.29 \\
\hline \multirow[t]{3}{*}{7.} & $\begin{array}{l}\text { IB technology has been widespread and handling of reproductive } \\
\text { problem by breeders }\end{array}$ & 0.092 & 4.00 & 0.37 \\
\hline & Total & \multicolumn{2}{|l|}{0,587} & 2.00 \\
\hline & \multicolumn{4}{|l|}{ Threats } \\
\hline 1. & Fluctuations in meat and beef prices & 0.085 & 2.00 & 0.13 \\
\hline 2. & The role of blantik greatly determines the price of livestock & 0.070 & 3.00 & 0.25 \\
\hline 3. & The conversion of agricultural / livestock land to other sectors & 0.066 & 2.00 & 0.13 \\
\hline 4. & Budget limitations or local government funds & 0.063 & 2.00 & 0.13 \\
\hline 5. & $\begin{array}{l}\text { Government policy on the importation of beef cattle seems to be less in } \\
\text { favor of breeders }\end{array}$ & 0.063 & 1.00 & 0.07 \\
\hline \multirow{3}{*}{6.} & Inefficient technology applications & 0.066 & 2.00 & 0.13 \\
\hline & Total & 0.413 & & 0.84 \\
\hline & Total & 1.000 & & 2.84 \\
\hline
\end{tabular}

Source: Primary Data processed, 2018.

The next SO strategy is to optimize the potential of the human resources of the breeders and support for animal feed waste as well as facilities and infrastructures for the development of beef cattle livestock. Breeders in Gunungkidul District have superior qualities which are unyielding and experiences which have been passed down through generations, support for potential animal feed, especially agricultural waste, including rice straw, corn, soybeans, cassava leaves, peanuts, sweet potatoes and supporting animal market facilities 
and infrastructure, Puskeswan (Animal Health Center) and easy transportation access which greatly support the development of beef cattle. This is in line with Wirdahayati's opinion (2010) that efforts to improve feed, utilization of local feed ingredients and waste of food crops and plantations which are easily accessed by the breeders, have opened up opportunities for livestock development efforts without relying on extensive traditional patterns by relying solely on natural pasture. Another SO strategy is to improve the management and technical cultivation skill in order to increase the productivity of beef cattle. The improvement activities of management and cultivation technical skill are in the form of facilities such as technical guidance, counseling, and technical assistance from the Office which is in charge of the functions of the livestock, Puskeswan (Animal Health Center) and counseling center. Alternative strategies for developing beef cattle livestock can be in the form of training for the breeders in terms of management and utilization of appropriate technology in livestock as well as increasing the quantity and quality of beef production (Khusna, et al., 2016). In addition, a research conducted by Putri, et al. 2016) state that optimization of counseling and mentoring program of livestock businesses through counseling program has an important role in transferring new innovation and appropriate technology, particularly for beef cattle livestock.

Table 5 - SWOT Matrix of Development of Beef Cattle Livestock in Gunungidul District

\begin{tabular}{|c|c|c|}
\hline & Strengths (S) & Weaknesses (W) \\
\hline External Factors & $\begin{array}{l}\text { S1 Regular recording (population) } \\
\text { S2 Unyielding nature } \\
\text { S3 Breeding experience } \\
\text { S4 Beef cattle base area } \\
\text { S5 Capital cost is relatively low } \\
\text { S6 Cultivation is easy to do } \\
\text { S7 Availability of agricultural waste } \\
\text { S8 Institutional group running } \\
\text { S9 Availability of animal markets and } \\
\text { transportation access }\end{array}$ & $\begin{array}{l}\text { W1 Low motivation to change business } \\
\text { orientation to profit/ business } \\
\text { W2 Capital limitation and difficult access } \\
\text { to Banking } \\
\text { W3 Side occupation/ savings } \\
\text { W4 Traditional system of individual } \\
\text { housing and small business scale } \\
\text { W5 Feed shortages during the dry } \\
\text { season } \\
\text { W6 The application of good cultivation } \\
\text { management is still lacking } \\
\text { W7 Lack of utilization of agricultural } \\
\text { waste } \\
\text { W8 The absence of marketing planning } \\
\text { and pricing is based on estimation }\end{array}$ \\
\hline Opportunities-O & SO Strategry & WO Strategy \\
\hline $\begin{array}{l}\text { O1 Avilability of market or demand } \\
\text { O2 There is facilities of Banking credit } \\
\text { O3 Government program facilities } \\
\text { O4 Determination of seed source area } \\
\text { O5 Trends in demand for religious } \\
\text { activities } \\
\text { O6 The existence of HPT processing } \\
\text { technology } \\
\text { O7 Widespread of IB technology and } \\
\text { handling of reproductive problem }\end{array}$ & $\begin{array}{l}\text { Increase of population and beef cattle } \\
\text { production in each sub-district based } \\
\text { on existing potential (S1, S2, S3, S4, } \\
\mathrm{S} 5, \mathrm{~S} 6, \mathrm{~S} 7, \mathrm{O} 1, \mathrm{O} 2, \mathrm{O} 3, \mathrm{O} 4, \mathrm{O} 5, \mathrm{O} 7) \\
\text { Optimization of the potential of } \\
\text { livestock human resources and support } \\
\text { from animal feed waste as well as } \\
\text { facilities and infrastructures for the } \\
\text { development of beef cattle breeding } \\
\text { (S2, S3, S4, S7, S9, O1, O3, O4, O6) } \\
\text { Improving good management and } \\
\text { technical cultivation skills to increase } \\
\text { the productivity of beef cattle (S2, S3, } \\
\text { S6, S8, O1, O3, O4, O5). }\end{array}$ & $\begin{array}{l}\text { Encourage an increase in the orientation } \\
\text { of business enterprises and increase the } \\
\text { capital for livestock development using } \\
\text { Banking facilities and government } \\
\text { program facilitaties (W1, W2, W3, W4, } \\
\text { W6, O1, O2, O3, O4) } \\
\text { The increase availability of animal feed } \\
\text { by utilizing government program } \\
\text { facilitaties and feed processing } \\
\text { technology (W5, W7, O3, O6) } \\
\text { Expand business networks and improve } \\
\text { the marketing capabilities of livestock } \\
\text { products (W1, W3, W8, O1, O5, O8) }\end{array}$ \\
\hline Threats-T & ST Strategy & WT Strategy \\
\hline $\begin{array}{l}\text { T1 Transfer of agricultural/ livestock land } \\
\text { functions } \\
\text { T2 Fluctuations in meat and beef prices } \\
\text { T3 The role of blantik to determine the } \\
\text { price } \\
\text { T4 Limitations of Regiona Government } \\
\text { budget } \\
\text { T5 Policy for importing beef cattle } \\
\text { T6 Technology application is less } \\
\text { efficient }\end{array}$ & $\begin{array}{l}\text { Socialization of the benefits and } \\
\text { advantages or potential of beef cattle } \\
\text { livestock to encourage business } \\
\text { interests and climate (S2, S3, S4, S5, } \\
\text { S6, S7, S8, S9, T1, T4, T5, T6). } \\
\text { Strengthen the institutional position of } \\
\text { groups in the form of legal entities or } \\
\text { cooperatives for the breeders (S1, S4, } \\
\mathrm{S} 8, \mathrm{~T} 2, \mathrm{~T} 3, \mathrm{~T} 4, \mathrm{~T} 5)\end{array}$ & $\begin{array}{l}\text { Improving the cooperation network/ } \\
\text { partnership and increasing the } \\
\text { investment with various institution and } \\
\text { business owners (W1, W2, W3, W4, W6, } \\
\text { T1, T2, T3, T4) }\end{array}$ \\
\hline
\end{tabular}

Source: Primary Data processed, 2018.

The WO strategy or weakness-opportunity strategy is a strategy to minimize the existing weaknesses in order to be able to utilize an external opportunity. Alternative 
strategies which can be formulated are encouraging an increase in the orientation of business ventures and increasing capital for the development of livestock using banking and government program facilities. The change in the orientation of breeder businesses towards businesses to gain profits is still low because of the limited capital. Capital constraint occurs because access to banking is difficult since it requires collateral. Therefore, the government programs facilities are needed to facilitate the access to banking. This is in accordance with Sodiq, et al opinion (2017) that breeders' access to capital has been one of the obstacles to improve breeders' businesses, so that it generally affects the national productivity. The weak capital structure of breeders is caused by the absence of assets which can be used as collateral, therefore revitalization of financing needs to be done through cooperation with various parties. Mukson, et al., 2014 state that the existing capital limitation in breeders is starting to be continuously improved with various beef cattle development programs, which are through food and energy security credit (KKPE), KUPS (Cattle Livestock Business Credit), Graduate Building Rural Area (SMD) and other development program schemes.

The next WO strategy is by increasing the availability of animal feed by utilizing government program facilities and feed processing technology. Lack of animal feed, especially in the dry season is still a serious problem. Therefore, it is necessary to make a special effort to utilize the potential of feed waste using appropriate technology and also need to be encouraged by an integrated breeding system with food crops, plantations and forestry. The combination of the development of beef cattle integrated with agricultural crops and the right strategy in gathering feed ingredients using an efficient cost approach as well as optimum nutritional quality will be able to keep the beef cattle productivity good and even more efficient than maintenance without using agricultural crops (Mariyono and Krisna, 2009). In order to ensure the availability of quality feed throughout the year, breeders need to be given training in feed processing technology such as feed storage technology, as well as agricultural waste-based feed processing technology and agro-industry (Putri et al., 2016).

The last WO strategy is by expanding the business network and improving the marketing capabilities of livestock products. Efforts to increase revenue or result are by improving an efficient marketing system, cutting long marketing chains and expanding marketing networks. Market development strategy iscarried out by marketing the product to a wider or far geographic market (Aisyah, 2013). According to Prastiti et al., 2016, alternative beef cattle development strategy is by optimizing the performance of existing marketing network. The strategy of optimizing the performance of the existing marketing network can be utilized by the providers of production facilities, breeders, agro-industry entrepreneurs and traders to sell their products.

The ST strategy or strength-threat strategy is a strategy to optimize the internal strengths in avoiding the threats. Alternative ST Strategy which can be formulated is strengthening the institutional position of group in the form of legal entities or cooperatives for breeders. The function of livestock group felt to be very beneficial for the group members. The government program facilitation or service and the ease of access to banking requires institutional groups which are already running. It is in line with Priyanto statement (2011) that the development of beef cattle business needs to be supported by institutions at the breeder level as well as at the institutional level/ program coordination in addition to capital. With the existence of a solid group, a business which can improve the bargaining position of the products will be formed. The second ST strategy is the socialization of the benefits and advantages or potential of beef cattle livestock in order to encourage business interest and climate. The existence of a beef cattle breeding business profile or agribusiness which is easy to do and able to increase breeders' income must be socialized since there is a reduced interest in raising livestock, especially the younger generation. This is in accordance with the statement from Putri et al, (2016) that at present, livestock has been viewed as an agribusiness system consisting of upstream subsystems (provision of livestock production facilities and seeds), on farm (production), to downstream (post-harvest, and marketing). With such a large potential of livestock business, without being followed by an increase in the quality of its human resources, the current breeders will only be on-farm workers with low income. 
WT strategy or weakness-threat strategy is a defensive strategy to minimize the internal weaknesses and avoid the external threats. Alternative strategies which can be formulated are increasing the cooperation networks/ partnerships and increasing investment with various institution and business owners. This is consistent with Suryana opinion (2009) that partnership is a collaborative activity between agribusiness actors ranging from preproduction, production to marketing, based on the principle of mutual need and benefit among the parties who work together, in this case the company and beef cattle breeders, to share costs, risks and benefits. This is in line with Sarma statement (2014) that alternative strategy by developing the integration strategy involving breeders, value chain actors and the meat processing industry, can increase the productivity through the transfer of cattle fattening technology, providing support services and sustainable market networks.

\section{CONCLUSION}

SWOT analysis showing the total score obtained from the internal factor analysis as the total strength score minus the total weakness score which is 0.81 and the external factor as the total opportunity score minus the total threat score which is 1.16 . The appropriate strategy in the development of beef cattle breeding is in quadrant I. The strategy which must be applied in this condition is by supporting the aggressive growth policies (Growth Oriented Strategy), which uses the power to obtain opportunities (SO). SO alternative strategies that can be formulated are increasing the population and production of beef cattle in each subdistrict based on existing potential, optimizing the potential of breeders' human resources and supporting animal feed waste as well as infrastructure for the development of beef cattle breeding, and improving the management and technical skills of the cultivation in order to increase the productivity of beef cattle in Gunungkidul District.

\section{REFERENCES}

1. Aisyah S.A., B. Sanim, A. Maulana. 2017. Strategi Pengembangan Usaha Sapi Potong (Studi Kasus Cv Mitra Tani Farm). J. Agripet (1)7: 60-66.

2. Anggaraini, 2017. Analisis Potensi Wilayah Dalam Pengembangan Peternakan Sapi Potong Di Kecamatan Sijunjung Kabupaten Sijunjung. J. AGRIFO 2 (2): 82-100.

3. Badan Perencanaan Pembangunan Daerah [Bappeda] Kab. Gunungkidul, 2016. Master Plan Pengembangan Peternakan Kabupaten Gunungkidul. Bappeda Kab. Gunungkidul.

4. Badan Pusat Statistik [BPS] Kabupaten Gunungkidul. 2016. Gunungkidul dalam Angka Tahun 2016. Gunungkidul. DIY.

5. Budiharsono, S. 2001. Teknik Analisis Pembangunan Wilayah Pesisir dan Lautan. PT. Pradinya Paramita. Jakarta.

6. David FR. 2009. Manajemen Strategis. Edisi 12. Jakarta (ID): Salemba Empat.

7. Distan DIY. 2015. Master Plan Pengembangan Kawasan Sapi Peranakan Onggole Di Daerah Istimewa Jogjakarta Tahun 2016-2020. Dinas Pertanian Provinsi Daerah Istimewa.

8. Hoda, A. 2002. Potensi Pengembangan peternakan sapi potong Usaha Tani Terpadu di Wilayah Maluku Utara. Tesis Program Pascasarjana Institut Pertanian Bogor. Bogor.

9. Mariyono, 2009. Pemanfaatan Dan Keterbatasan Hasil Ikutan Pertanian Serta Strategi Pemberian Pakan Berbasis Limbah Pertanian Untuk Sapi Potong. Wartazoa. 1(19): 3142.

10. Khusna, A., H.K. Daryanto, M.M.D. Utami. 2016. Pengembangan Strategi Agribisnis Sapi Potong di Kabupaten Gunungkidul (Agribusiness Strategy Development of Beef Cattle in Gunungkidul District). Jurnal IImu Pertanian Indonesia (JIPI). 21 (2): 69-75.

11. Mukson, S. Marzuki, P. I. Sari, dan H. Setiyawan. 2008. Faktor-faktor yang mempengaruhi potensi pengembangan ternak sapi potong rakyat di Kecamatan Kaliori Kabupaten Rembang, Jawa Tengah. J. Indon.Trop. Anim. Agric. 33: 305-312. 
12. Mukson, W. Roessali dan H. Setiyawan.2014. Analisis Wilayah Pengembangan peternakan sapi potong dalam Mendukung Swasembada Daging di Jawa Tengah. J. Peternakan Indonesia. 16 (1): 26-32.

13. Prastiti. R.A., W.Arip. Agribusiness Development Strategies of Beef Cattle in Blora District, Online available from http: //agribisnis.fp.uns. ac. Id.

14. Priyanto.D. 2011. Strategi Pengembangan Usaha Ternak Sapi Potong Dalam Mendukung Program Swasembada Daging Sapi Dan Kerbau Tahun 2014. Jurnal Litbang Pertanian, 30(3), 2011: 108-116.

15. Putri BRT, 2014. Strategy of Business Management and Agribusiness System of Bali Cattle Breeding to Improve Farmers Income. Journal of Animal Science. 3(2): 1-7.

16. Rohaeni, E.S., B. Hartono, 2014. Strategy of the Sustainable Development of Beef Cattle in Tanah Laut District, South Kalimantan, Indonesia IOSR Journal of Agriculture and Veterinary Science (IOSR-JAVS) Volume 7, Issue 11 Ver. II (Nov. 2014), PP 49-57.

17. Sarma PK. 2014. An Agribusiness Development Approach of Beef Cattle In Selected Areas Of Bangladesh. Journal of the Bangladesh Agricultural University. 12(2): 351-358.

18. Sodiq, A., 2017. Sistem Produksi Peternakan Sapi Potong di Pedesaan dan Strategi Pengembangannya. Jurnal Agripet, 17(1): 60-66.

19. Suryana. 2009. Pengembangan Usaha Ternak Sapi Potong Berorientasi Agribisnis Dengan Pola Kemitraan. J. Litbangtan. 28 (1): 29-37.

20. Suresti. A, dan R. Wati. 2012. Strategi Pengembangan Usaha Peternakan Sapi Potong di Kabupaten Pesisir Selatan. Jurnal Peternakan Indonesia. Vol. 14 (1): 249-262

21. Sugiyono. 2009. Metode Penelitian Kuantitatif Kualitatif. Alfabeta, Bandung.

22. Waris, N. Badriyah, 2015. Pengaruh Tingkat Pendidikan, Usia, Dan Lama Beternak Terhadap Pengetahuan Manajemen Reproduksi Ternak Sapi Potong Di Desa Kedungpring Kecamatan Balongpanggang Kabupaten Gresik. Jurnal Ternak Vol. 06 No.01: 30-33.

23. Wirdahayati R.B. 2010. Penerapan Teknologi Dalam Upaya Meningkatkan Produktivitas Sapi Potong Di Nusa Tenggara Timur. Wartazoa. (20) 1: 12-20.

24. Widiati,R. 2014.Membangun Industri Peternakan Sapi Potong Rakyat Dalam Mendukung Kecukupan Daging Sapi. Wartazoa 24(4): 191-200.

25. Yusdja Y., 2003. Profil dan Permasalahan Peternakan. Forum Pen. Agroekon. 21(1): 4456. 